U. S. DEPARTMENT OF THE INTERIOR

U. S. GEOLOGICAL SURVEY

\title{
SKARN-HOSTED MINERALIZATION IN PALEOZOIC ROCKS \\ BENEATH THE IDARADO MINE, NORTHWEST SAN JUAN MOUNTAINS, COLORADO
}

by

James N. Mayor ${ }^{1}$ and Frederick S. Fisher ${ }^{2}$

Open-File Report 93-183

This report is preliminary and has not been reviewed for conformity with U.S.

Geological Survey editorial standards or with the North American Stratigraphic Code. Any use of trade, product, or firm names is for descriptive purposes only and does not imply endorsement by the U. S. Government.

${ }^{1}$ Newmont Mining Corporation

Denver, CO

${ }^{2}$ U.S. Geological Survey

Tucson, AZ 


\begin{abstract}
Three vertical holes were drilled and cored to examine Paleozoic rocks for mineralization beneath the Idarado Mine. The holes are sited along the highly productive Argentine-Black Bear-Cross Vein systems on the northwest side of the Silverton caldera.

With the exception of the Cross Vein-Argentine Vein intersection, economic mineralization at the Idarado mine essentially bottoms at the Tertiary unconformity in the Telluride Conglomerate. The junction between the Cross and Argentine veins apparently served as a major conduit for ore fluids and is well mineralized at an elevation of 9,100 feet (2900 Mill level) in the Permian Cutler Formation.

Calcareous rocks of the Hermosa, Molas, Leadville, Ouray and Elbert formations were metasomatized. Relatively pure carbonates were recrystallized to tremolitic marble while impure siliceous limestones were altered to calc-silicate skarn.

A variety of skarn types are noted. In the Hermosa Formation, this includes rhodonite-epidote, epidote-diopside and epidote-actinolite types. The most extensive skarn is at the top of the Leadville Formation in hole Tb29-H-1. Skarn types there include a combination of: rhodonite, ilvaite, johannsenite, garnet, and magnetite. Calc-silicates are manganiferous.

Base metal mineralization is present with the skarns; $\mathrm{Zn}$ and $\mathrm{Pb}$ values correlate well with the presence of Mn. Skarn appears to have formed at a relatively high temperature; base metals are later and replace the earlier formed skarn.
\end{abstract}

\title{
Structure
}

\section{GEOLOGICAL SETTING}

A complex of Tertiary-age calderas is the dominant geologic feature in the northwest San Juan Mountains and consists of the Uncompahgre and San Juan calderas (28 m.y.), the Silverton caldera (27 m.y.), and the Lake City caldera (22.5 m.y.) (Lipman et al., 1973). Bounding faults of the Silverton caldera pass through the Idarado property that is situated along its northwest edge (Figure 1).

At the Idarado mine, normal faults radial to the caldera have been filled by both veins and dikes; in plan, these structures form an elongate belt with a long axis that trends $\mathrm{N}^{\circ} 5^{\circ} \mathrm{W}$ from the edge of the Silverton caldera to the vicinity of the Mt. Sneffels-Stony Mountain intrusion. In general, the dikes and structures dip steeply outward from the central axis.

At the Idarado Mine, base and precious metal ores have been mined from both veins and replacement deposits in Telluride Conglomerate along individual fissures that strike $\mathrm{N} 15-70^{\circ} \mathrm{W}$ within the system (Mayor and Fisher, 1972).

\section{Stratigraphy}

In the mine area, west-dipping Mesozoic and Paleozoic strata rest on quartzite of the Precambrian Uncompahgre Formation; the Paleozoic rocks extend east of the mine area and wedge out along a line that extends southward from Ouray to Silverton. These units are separated by a major angular unconformity from overlying nearly horizontal Tertiary formations that include the basal Telluride Conglomerate and several thousand feet of overlying volcanic rocks (Mayor, 1978). A generalized stratigraphic column is shown in Table 1. 


\section{PRODUCTION}

The total production of the Idarado property has been given elsewhere (Mayor, 1978); that portion produced by Idarado mining company is shown below:

$\begin{array}{ccccccc}\underline{\text { Year }} & \underline{\text { Tons }} & \underline{\mathrm{Au} \mathrm{oz} / \mathrm{t}} & \underline{\mathrm{Ag} \mathrm{oz} / \mathrm{t}} & \underline{\mathrm{Pb} \%} & \underline{\mathrm{Cu} \%} & \underline{\mathrm{Zn} \%} \\ 1946-1978 & 10,900,000 & 0.07 & 1.91 & 2.33 & 0.71 & 3.63\end{array}$

Approximately $95 \%$ of this production was from vein structures and Telluride Conglomerate replacement ores of the Argentine-Black Bear-Cross Vein system.

\section{SOURCE OF DATA}

Three diamond drill holes were completed between 1974-1978 to examine the Paleozoic rocks for the presence of mineralization beneath the Idarado Mine. These are shown in Figure 2 and form the database for this report. Placement of the drill holes in relation to the vein conduits and ore shoots, that are hosted in the Tertiary rocks, is summarized below.

Although some vein and dike structures are present in the Paleozoic rocks, economic mineralization essentially bottoms at the Tertiary unconformity within the Telluride Conglomerate at approximately 9,400 feet elevation.

The vicinity of the Cross and Argentine Vein intersection, is the notable exception. On 2900 level, ore-grade vein mineralization is present for $2,600 \mathrm{ft}$ along the Cross Vein system and $900 \mathrm{ft}$ along the Argentine Vein in the Permian Cutler Formation.

Drill hole Tb29-H-1 is situated central to the Argentine vein and replacement ore shoots and positioned to test the Paleozoic rocks at the ArgentineCross Vein intersection projected to depth. Drill hole Tb29-H-3 is an offset to the mineralized skarn intersected by Tb29-H-1.

The 2400 level (9,500' elevation) is the lowest level along the Black Bear vein. Mine development has exposed a braided system of narrow veins characterized by steep dips. Along the Black Bear, the strike length of vein ore shoots narrows with depth from $4,000 \mathrm{ft}$ at 1200 level to approximately $1,000 \mathrm{ft}$ at the 2400 level.

Drill hole BB24-14-1 is situated central to the Black Bear ore shoots.

\section{LITHOLOGY OF DRILL CORES, CORRELATION BETWEEN DRILL HOLES AND THE STRATIGRAPHIC POSITION OF SKARNS.}

The stratigraphic correlation of altered rocks in drill holes TB29-H-1, Tb 29H-3 and BB24-14-1 is shown in Figure 3 and Table 5. 
Hermosa Formation

The Hermosa Formation is predominantly arenaceous, similar to the overlying Cutler, with relatively thin units of conglomerate and siltstone.

Interbedded limestones become increasingly common with depth and range from 1 $\mathrm{ft}$ to $22 \mathrm{ft}$ in thickness.

The sandstones are feldspathic with significant amounts of K-feldspar, mostly microcline, in addition to plagioclase. Alteration within the sandstones is generally slight and consists of epidotized plagioclase; minor amounts of calcite, actinolite, chlorite, and sericite occur sporadically throughout the sandstone interstices.

The siltstones are reddish-brown and highly ferruginous (hematitic) near the top of the Hermosa, becoming reduced and carbonaceous near the base. They typically comprise $30 \%-40 \%$ quartz, $3-15 \%$ plagioclase, $3-5 \%$ microcline, in addition to matrix micas and illitic clays. Carbonaceous siltstones are slightly pyritic with traces of pyrrhotite and chalcopyrite. Siltstones are observed to grade into limestones. The limestones are typically altered to skarn along contacts.

\section{Molas Formation}

The most intense skarn is developed at depth in holes Tb29-H-1 and BB2414-1 (Table 5). Unaltered rock is not present within the skarn, but by correlation both with the regional stratigraphic section and the less altered rocks of drill hole TB29-H-3, these skarns are interpreted to have developed principally at the horizon of the Molas Formation.

The Molas was deposited on a karst surface and thickness can vary over short distances. This feature may explain, in part, the difference in the thickness of skarn between holes Tb29-H-1 and Tb29-H-3. Alternatively, some of the adjacent Hermosa could be included in the skarn.

In BB24-H-1, the 164' of garnet-epidote skarn must include a significant thickness of the lower Hermosa Formation.

\begin{tabular}{||l|l|l|l||}
\hline \multicolumn{4}{|c||}{ TABLE 5 } \\
CORRELATION OF LOWER PALEOZOIC AND PRECAMBRIAN ROCKS \\
BETWEEN THE IDARADO DRILL HOLES \\
\hline \hline Formation & 'Tb29-H-3 & Tb29-H-1 & BB24-14-1 \\
\hline Molas & $9.2^{\prime}$ 'sedimentary bx & $36.0^{\prime}$ 'skarn & $164.0^{\prime}$ garnet-epidote skarn ${ }^{(1)}$ \\
\hline Leadville & $118.3^{\prime}$ marble & $113.5^{\prime}$ marble & $55.0^{\prime}$ garnet skarn \\
\hline Ouray-Elbert & $166.0^{\prime}$ dol-ls, sh, sst & $156.6^{\prime}$ dol-ls, sh, ss. & $131.5^{\prime}$ marble, hornfels \\
\hline Precambrian & $5.0^{\prime}$ ' quartzite & $3.0^{\prime}$ quartzite & $\begin{array}{l}100.0^{\prime} \text { gneiss } \\
6.0^{\prime} \text { monzonite }\end{array}$ \\
\hline
\end{tabular}

(1) includes lower Hermosa Formation. 
Leadville, Ouray and Elbert Formations

The Leadville, Ouray and Elbert Formations are dominated by carbonate rocks and appear to thin to the southeast.

The Leadville, in hole Tb29-H-1, comprises 113.5' of calcitic marble whereas to the southeast in BB24-14-1, the Leadville appears to be represented by 55' of massive garnet skarn.

The Ouray-Elbert Formations comprise alternating beds of limestone, dolomitic limestone, shale and sandstones. The total thickness of these Formations changes from 156.6 feet to 131.5 feet between holes $\mathrm{Tb} 29-\mathrm{H}-1$ and BB24-14-1, respectively.

\section{Precambrian}

Precambrian rocks change in lithology to the southeast. Drill holes Tb29-H1 and Tb29-H-3 terminate in 3 feet and 5 feet, respectively of "typical" pure quartzite of the Uncompahgre Formation.

The Precambrian rocks of BB24-14-1 comprise 100' of gneiss followed by 6' of weakly foliated monzonite at the end of the hole.

The composition of these metamorphic rocks in BB24-14-1 is variable with quartz (9-27\%), K-feldspar (10-42\%) and plagioclase (23-41\%), the dominant minerals.

The most likely correlation of these rocks is with the Twilight Gneiss or Tenmile Granite that outcrop 17 miles to the south.

\section{ALTERATION-MINERALIZATION IN PALEOZOIC ROCKS}

Based on the abundance of garnet, epidote, tremolite-actinolite and the presence of marble, the alteration intensity increases with depth in each hole. In addition, the alteration in BB24-14-1 is more widespread than the other holes and may indicate an increase in the thermal gradient to the southeast.

Skarns in the Hermosa Formation

The thin interbedded limestones within the Hermosa Formation are typically altered to skarn along contacts or throughout (in the case of thinner beds) and result in a range of mineralogic composition.

Moderately pure or slightly dolomitic limestones were recrystallized to tremolitic marble. Impure siliceous limestones were altered to calc-silicate skarn consisting of manganiferous epidotes, pyroxenes, amphiboles and garnets. Skarns are classified into three types: rhodonite-epidote, epidote-diopside, epidoteactinolite.

Base metal mineralization ( $\mathrm{Pb}$ and $\mathrm{Zn}$ with minor $\mathrm{Cu}$ ) occurs principally as replacements along the metasomatized skarn horizons. Skarn types are shown on Table 2; rhodonite-epidote is the most favorable skarn type for base metal mineralization. 
Skarns in the Molas Formation

Drill Hole Tb29-H-1

Considerable diversity in mineralogic composition is present in skarn of Tb29-H-1 (Table 3I). The Calc-silicate minerals are manganiferous. Base metal values $(\mathrm{Zn}$ and $\mathrm{Pb})$ correlate with the $\mathrm{Mn}$ content of the skarn and may serve as a guide to mineralization (Table 3II). The assay value for the mineralized skarn is 36 feet, Nil Au, $0.24 \mathrm{oz} / \mathrm{t} \mathrm{Ag}, 1.16 \% \mathrm{~Pb}, 0.03 \% \mathrm{Cu}$, 2.43\% Zn (Table 3III).

The skarn appears to have developed at relatively high temperature prior to base metal mineralization and was subsequently mineralized during stages of declining temperature and surges of hydrothermal activity. In thin section, quartz, calcite, hematite-magnetite and base metals can be seen to replace silicates.

Sphalerite distribution is irregular and ranges from fairly massive replacements to small dispersed grains. Sphalerite replacement is not restricted to a specific rock type and was detected in garnet-magnetite and pyroxene-rhodonite skarn types. It appears that permeability and replaceable silicates are important factors in controlling the distribution of sulphides within the skarn mineral assemblage.

\section{Drill Hole Tb29-H-3}

This drill hole is an offset from $\mathrm{Tb} 29-\mathrm{H}-1$ in a direction toward the Argentine Vein, to test the continuity of the mineralized intercept in Tb-29$\mathrm{H}-1$.

An 11.7 feet thickness of garnet-epidote skarn with minor base metals was intersected at the contact with the underlying 9.2 feet unaltered sedimentary chert clast breccia that is correlated with the Molas Formation.

\section{Drill Hole BB24-14-1}

The skarns of hole BB24-14-1 are of relatively simple mineralogy (Table 4I). Between 2,668-2,832 ft, epidote(0-75\%)-andradite(3-88\%) skarn dominates with lesser plagioclase, $\mathrm{K}$-feldspar, quartz, sericite, amphibole and specular hematite. Some green grossularite is common locally with the andradite.

From 2,832 $\mathrm{ft}$, the skarn mineralogy changes abruptly to pure garnet skarn; in thin section, anhedral unzoned garnet have euhedral zoned garnet overgrowths.

Base metal mineralization in these skarns is weak (Table 4II) and may indicate unreactive silicates or distance from the source of fluids. 


\section{ACKNOWLEDGMENT}

We acknowledge the cooperation of the Idarado Mining Company and the Newmont Mining Corporation for allowing access to the Idarado Mine, drill core and company records, and for permission to publish the data.

The mineralogic work of D.M. Hausen, J.R. Odekirk, W. Mueller, and M. Supp, documented in internal company reports, is acknowledged. 


\section{Illustrations}

TABLES

Table 1 Generalized Stratigraphic Column

Table 2 Idarado Mine DDH Tb29-H-1. Hermosa Skarns and Assays (XRF)

Table 3 Idarado Mine DDH Tb29-H-1 Molas Skarns

I) X-Ray diffraction mineralogy

II) Geochemistry

III) Assays of mineralized skarn

Table 4 Idarado Mine DDH BB24-14-1.

I) X-ray diffraction mineralogy

II) Geochemistry

Table 5 Correlation of Lower Paleozoic and Precambrian Rocks between the Idarado Drill Holes.

\section{FIGURES}

Figure 1 Generalized Geologic Map Showing Structure Relations of the Silverton Caldera (after Burbank 1947)

Figure 2 Composite Mine Plan Showing Location of Drill Holes

Figure 3 Vertical Projection of Drill Holes to Show Lithologic Correlation and Stratigraphic Position of Skarns. 


\section{$\underline{\text { References Cited }}$}

Lipman, P.W., Steven, T.A., Luedke, R.G., and Burbank, W.S.

(1973) Revised volcanic history of the San Juan, Uncompahgre, Silverton, and Lake City Calderas in the western San Juan Mountains, Colorado: U.S. Geol. Survey Journal Research, Vol. 1, pps. 627-642.

Mayor, J.N., and Fisher, F.S. (1972) Middle Tertiary replacement ore bodies and associated veins in the northwest San Juan Mountains, Colorado: Econ. Geol., Vol. 67, pps. 214-230.

Mayor, J.N. (1978) Geologic summary of the Idarado Mine, Ouray County, Colorado, in Professional Contributions of Colorado School of Mines, No. 9. 
TABLE 1. Generalized Stratigraphic Column of Rock Units in the Northwest San Juan Mountains [Adapted from Burbank (1947) and Fisher, [nedke, Shcridan, and Raabe (1968)]

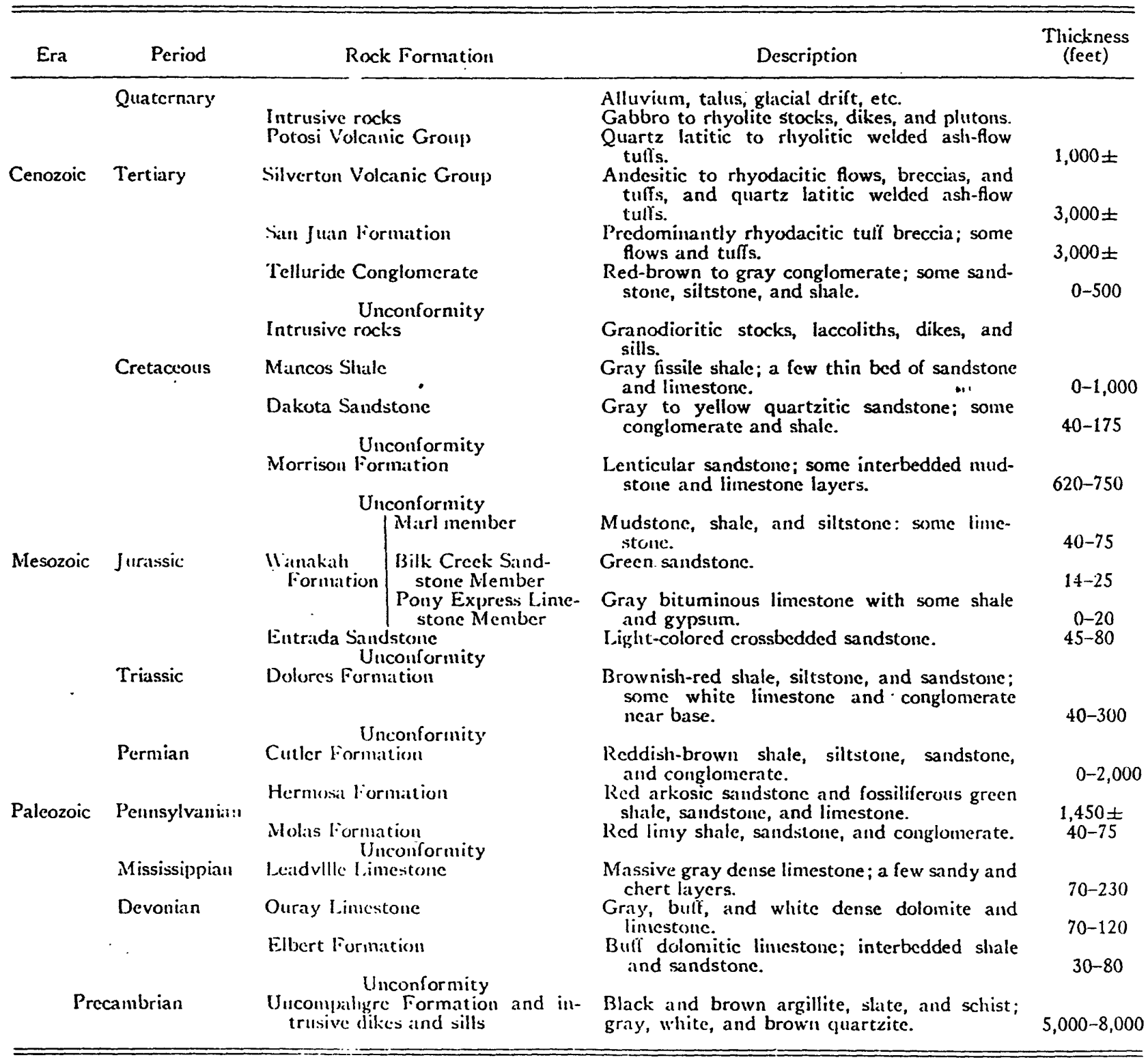


TABLE 2

DARADO MINE DDH TB29-H-1 - CORE SAMPLES

HERMOSA SKARNS, ROCK TYPES AND ASSAYS (XRF)

\begin{tabular}{|c|c|c|c|c|c|c|}
\hline Depth (ft) & Formation & Rock Type & $\% \mathbf{Z n}$ & $\% \mathbf{P b}$ & $\% \mathbf{C u}$ & $\% \mathbf{M n}$ \\
\hline 739 & Hermosa & Rhodonite-epidote skarn & 1.98 & 1.27 & $<0.01$ & 14.2 \\
\hline 943 & $"$ & Feldspathic sandstone & $<0.01$ & $<0.01$ & 0.02 & $<0.1$ \\
\hline 975 & $"$ & Epidotized sandstone & 0.02 & 0.01 & $<0.01$ & 0.4 \\
\hline 980 & $"$ & Rhodonite-epidote skarn & 5.27 & 1.59 & $<0.01$ & 11.5 \\
\hline 993 & $"$ & Ferruginous siltstone & $<0.01$ & $<0.01$ & $<0.01$ & $<0.1$ \\
\hline 1002 & $"$ & Epidotized sandstone & $<0.01$ & $<0.01$ & 0.02 & 0.1 \\
\hline 1464 & $"$ & Carbonaceous siltstone & $<0.1$ & 0.02 & 0.02 & 0.1 \\
\hline $1468(a)$ & $"$ & Carbonaceous silt, limestone & $<0.01$ & $<0.01$ & $<0.01$ & 0.3 \\
\hline $1468(b)$ & $"$ & Epidote-actinolite skarn & 0.02 & 0.02 & $<0.01$ & 0.3 \\
\hline 1543 & $"$ & Epidote-actinolite skarn & 0.03 & 0.02 & 0.04 & 0.4 \\
\hline 2112 & $"$ & Carbonaceous limestone & $<0.01$ & 0.01 & $<0.01$ & $<0.1$ \\
\hline 2164 & $"$ & Carbonaceous siltstone & 0.02 & $<0.01$ & 0.02 & $<0.1$ \\
\hline 2165 & $"$ & Chloritic sandstone & 0.10 & 0.03 & 0.39 & 0.2 \\
\hline 2174 & $"$ & Feldspathic sandstone & 0.03 & $<0.01$ & 0.01 & 0.1 \\
\hline 2178 & $"$ & Feldspathic sandstone & $<0.01$ & $<0.01$ & $<0.01$ & $<0.1$ \\
\hline 2192(a) & $"$ & Tremolitized limestone & $<0.01$ & $<0.01$ & $<0.01$ & 0.1 \\
\hline 2192(b) & $"$ & Epidote-actinolite skarn & 0.02 & 0.02 & $<0.01$ & 0.3 \\
\hline 2197 & $"$ & Epidote-diopside skarn & 0.05 & $<0.01$ & 0.03 & 0.4 \\
\hline 2202 & $"$ & Carbonaceous siltstone & 0.04 & $<0.01$ & $<0.01$ & $<0.1$ \\
\hline 2215 & $"$ & Epidote-diopside skarn & 0.15 & $<0.01$ & 0.02 & 0.4 \\
\hline 2245 & $"$ & Epidote-diopside skarn & 0.10 & 0.02 & 0.02 & 2.0 \\
\hline 2257 & $"$ & Feldspathic sandstone & $<0.01$ & $<0.01$ & $<0.01$ & $<0.1$ \\
\hline
\end{tabular}




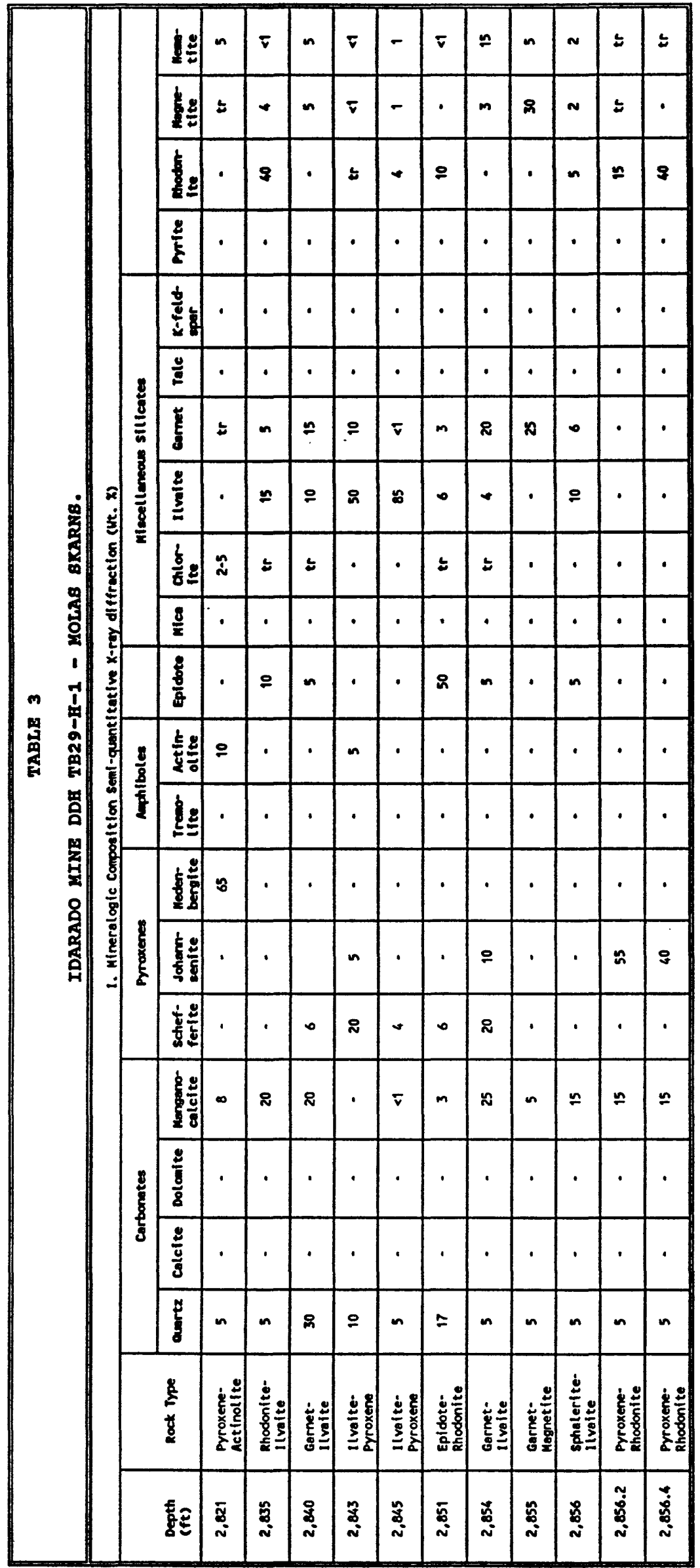

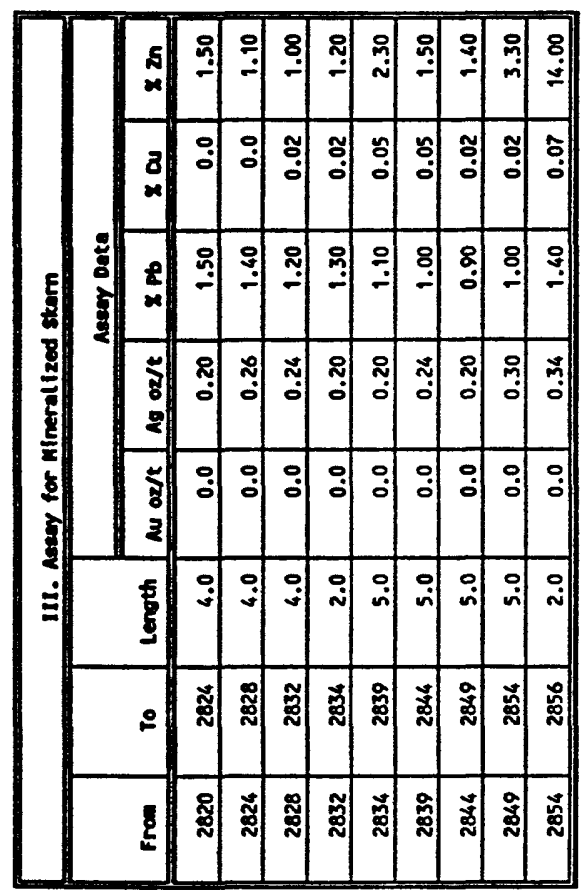

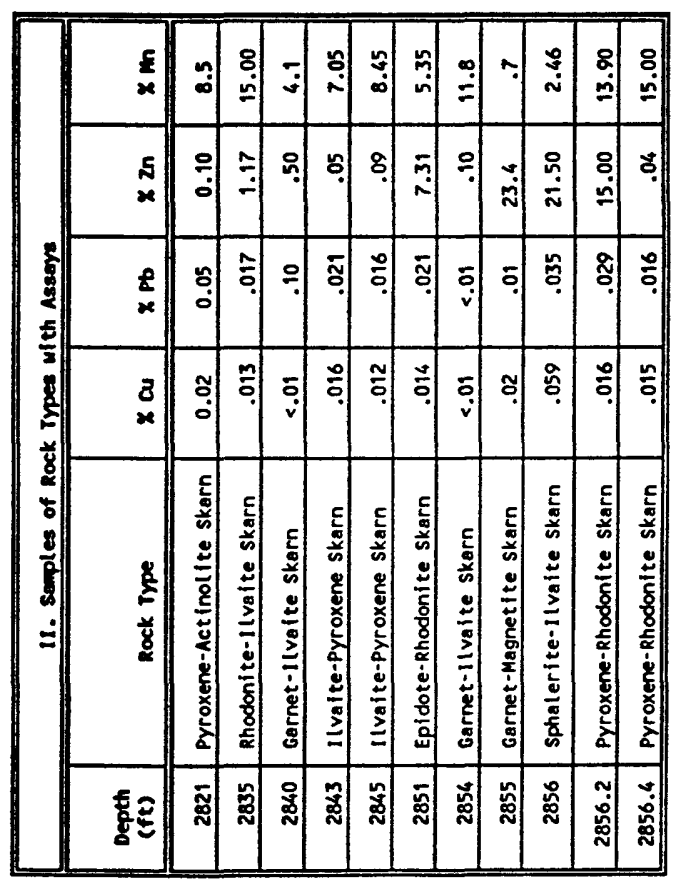




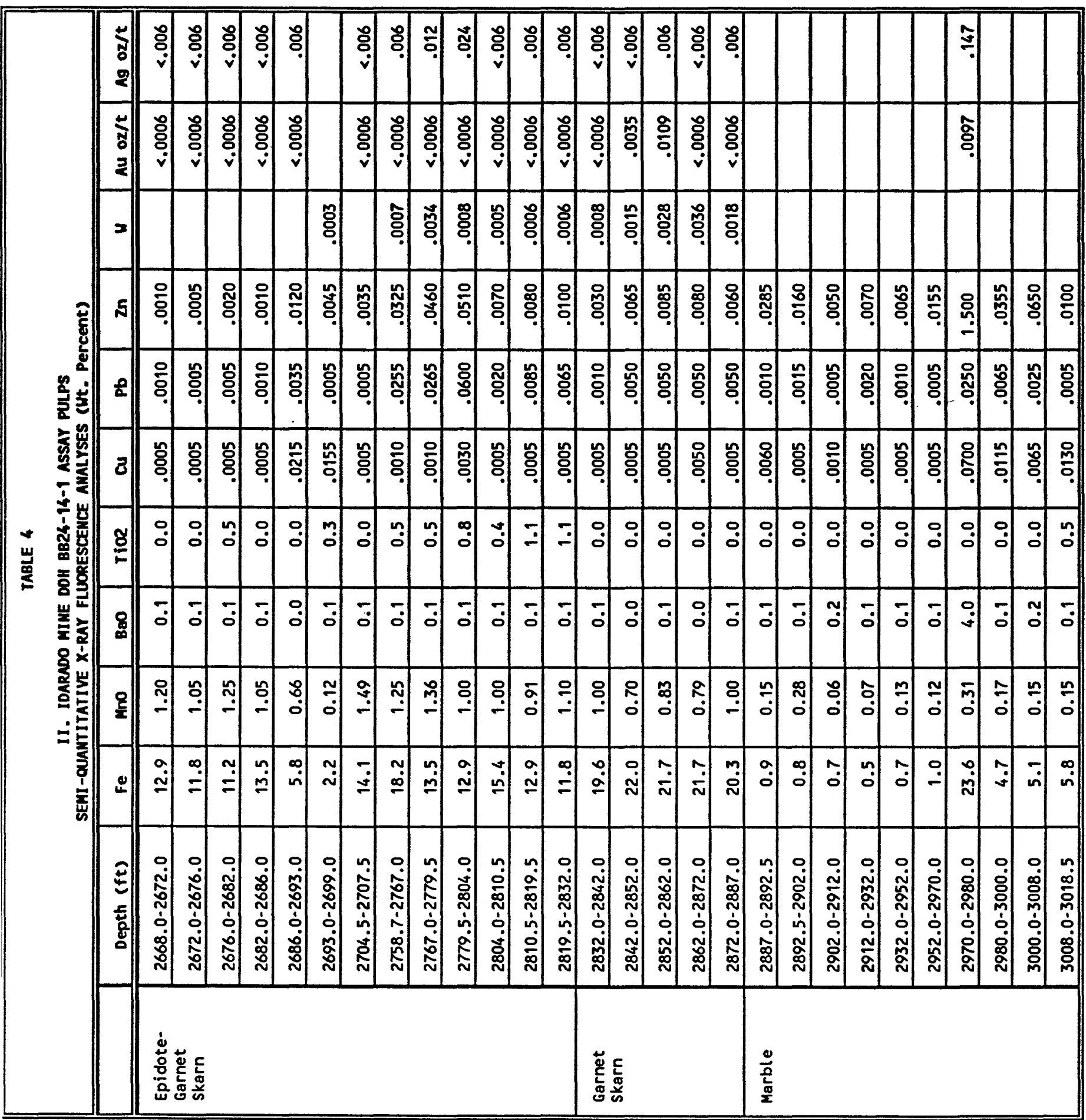


辤

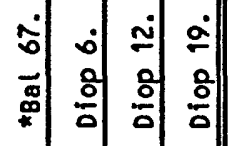

爱

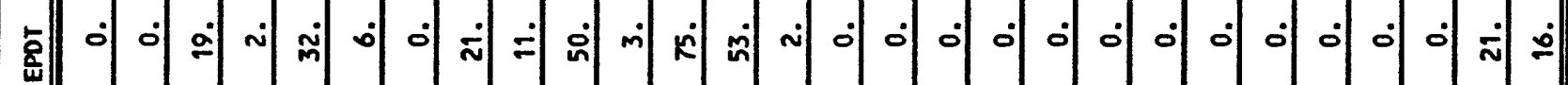

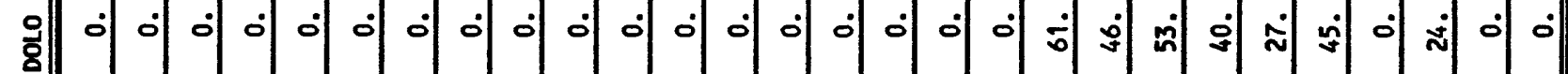

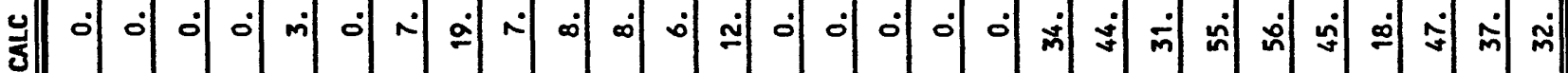

乡

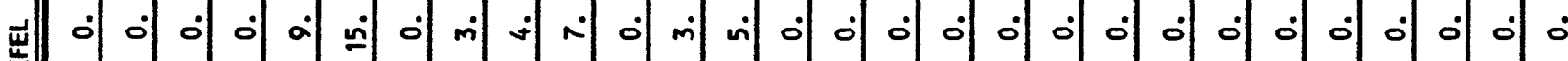

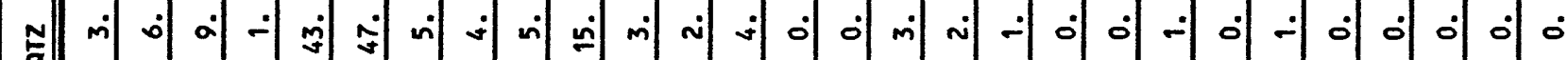

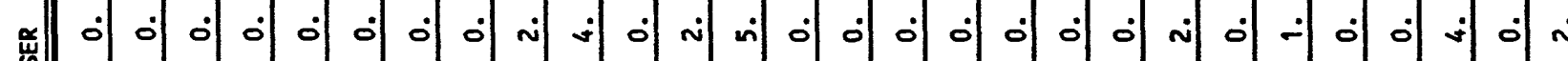

0.00 .00 .0

$$
+
$$

$+2$

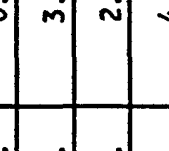

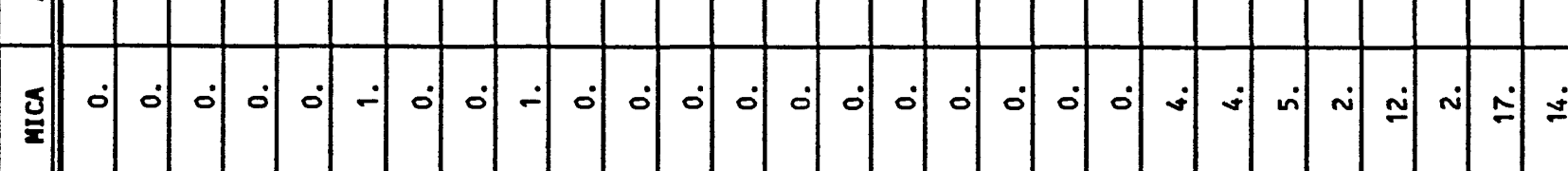

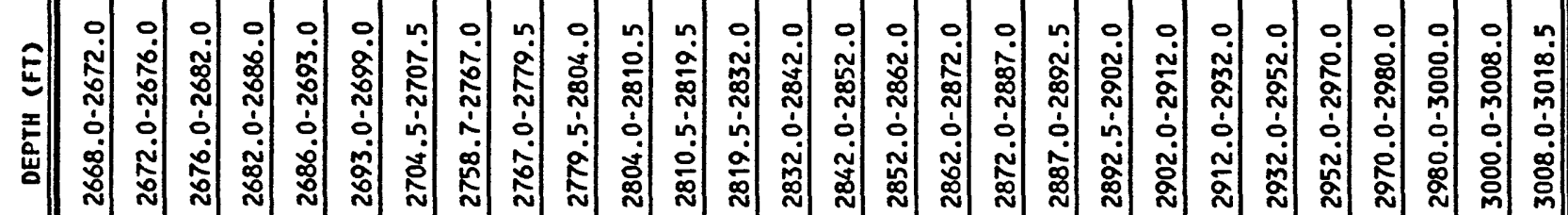




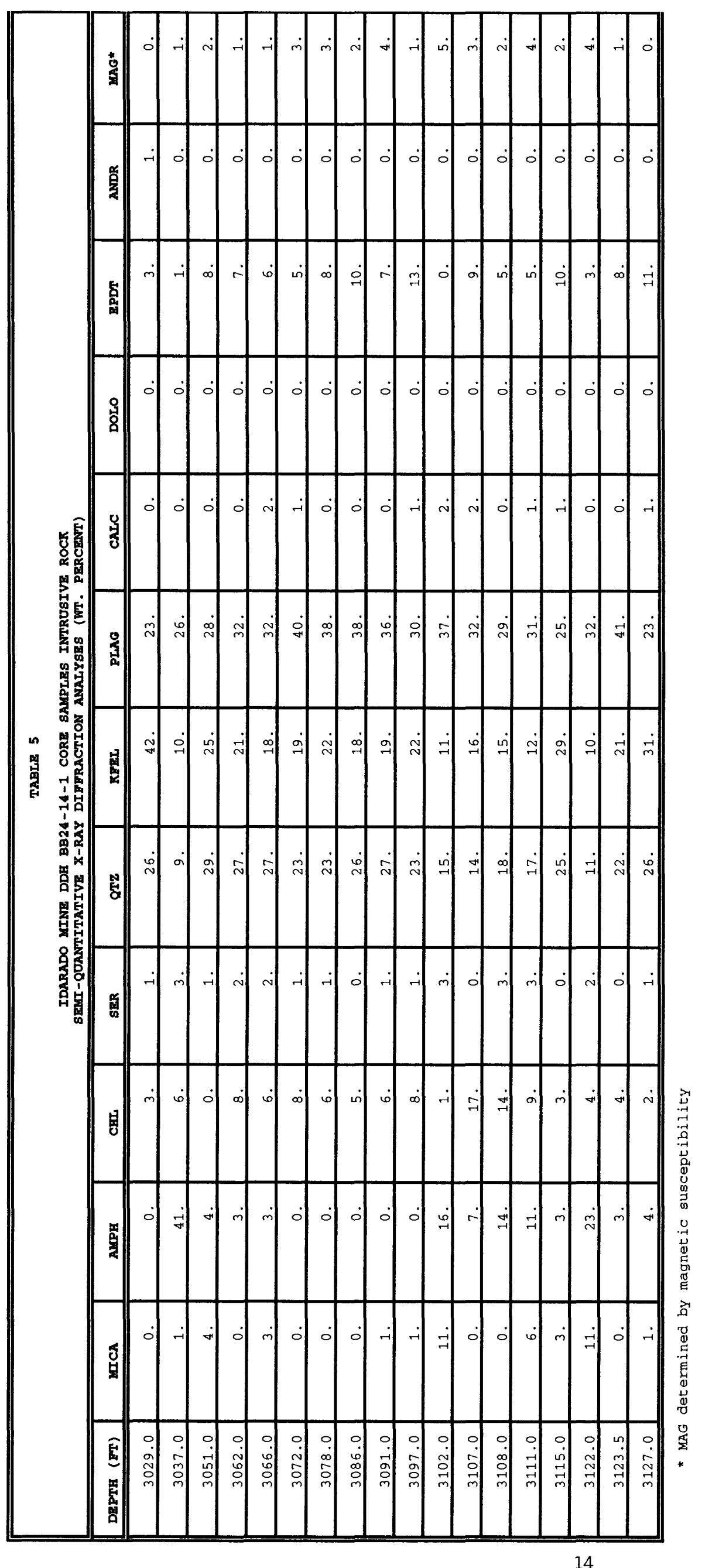



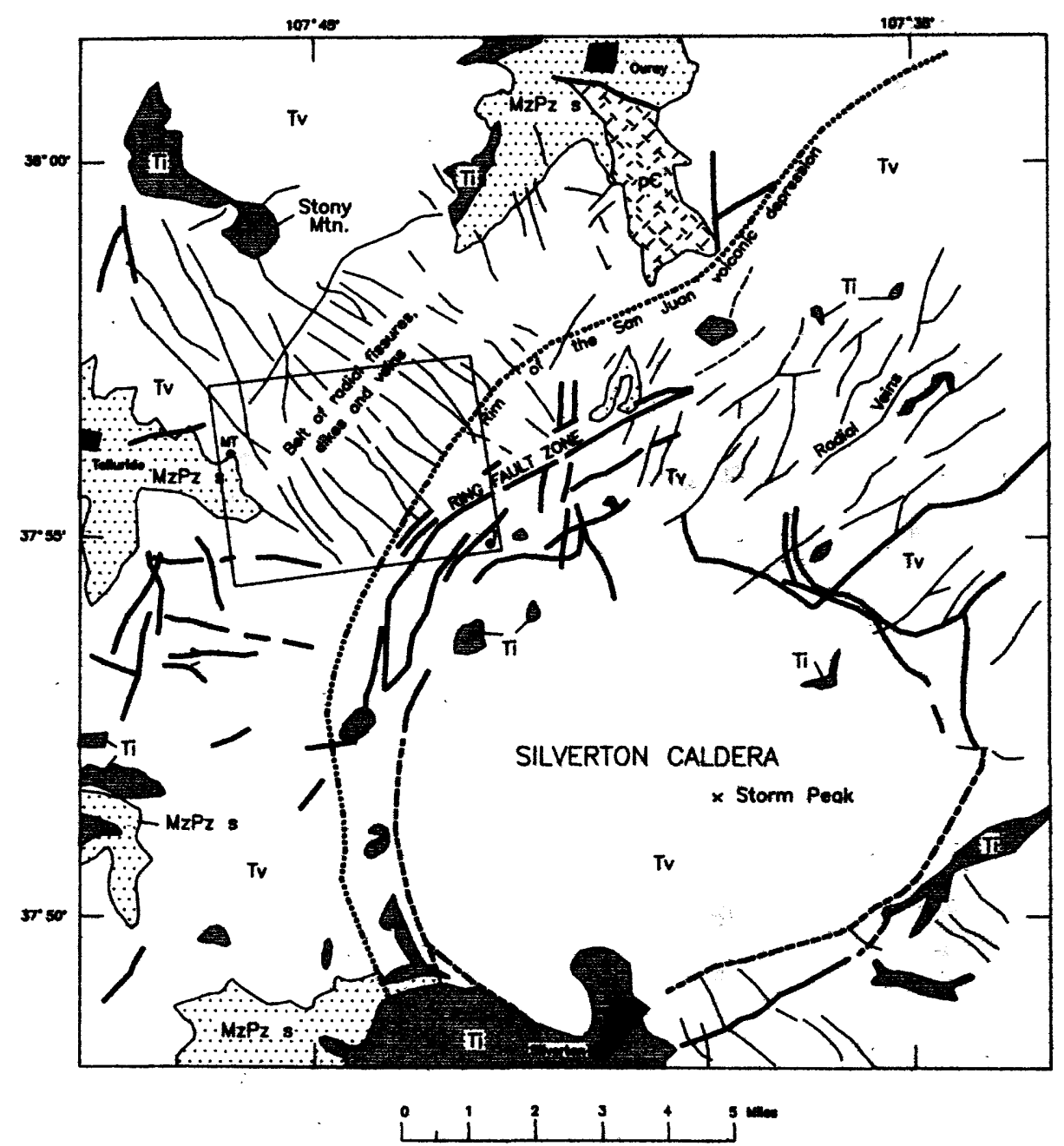

EXPLANATION

Tertiary volcanic formations

(Telluride Conglomerote included where present ot base)

MzPz Mesozoic and Paleozoic

MrPz.: Mesozic and Poleoz

Kìc's

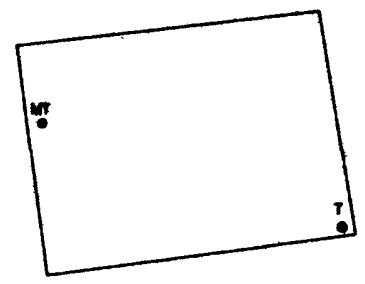

Outline of Figure 2

Idorodo's

MT - Mill Tunnel

$T$ - Treosury Tunnel

Precambrian rocks

Contact

Mojor foult, doshed where opproximately located

Principal fissures. dikes, veins and minor foults

Figure 1

Generalized geologic map showing structural relations of the Silverton caldera, after Burbank (1947) 
